\title{
SPATIAL HETEROGENEITY OF LAND TAXATION IN UKRAINE: THE IMPACT OF DECENTRALIZATION
}

\author{
Hunko Liudmyla, Moroz Yuliia \\ National University of Life and Environmental Sciences of Ukraine
}

\begin{abstract}
Starting in 2016, the process of financial decentralization began in Ukraine, in which local governments of lower levels (rural, urban, city councils and united territorial communities) were entitled to independently establish on their territory the rates of many local taxes and fees credited to community budgets. In particular, tax legislation of Ukraine allows local governments to vary land tax rates in the range from 0.1 to $3 \%$ of the normative monetary valuation of land, as well as to differentiate tax rates depending on the type of intended use of land plots. The study created a database and analyzed the spatial heterogeneity of land tax rates in more than 9.6 thousand communities. It is shown how the level of tax burden on land owners and land users, established by local self-government bodies, correlates with the economic development of the regions, as well as the normative monetary valuation of land, which is used in Ukraine as a tax base. The problems of taxation of real estate, which arise at the separate collection of land tax and tax for real property other than land, are considered, as well as suggestions on the necessity of introduction of tax zoning of territories in Ukraine, which will allow to further differentiate the rates of taxes on the property and provide more flexible and adaptive taxation of real estate.

Key words: decentralization, land-use, land tax, normative monetary, valuation of land, taxation.
\end{abstract}

\section{Introduction}

The world economic experience shows that the economic, social, political state of local development is better understood and can be reformed by local authorities. Successful top-ranked authorities have diverged from various resources and should be open to scrutinizing government functions that occur throughout the year (Khotenko, at al, 2017). It is the authorities that form the tax system, thereby determining the economic relations between the entities and the state (Vdovichenko, at al, 2019). Local authorities can create favourable conditions for economic growth on the ground, use all levers for the development of entrepreneurship, small and medium-sized businesses, help create new jobs and increase self-employment of the population. The process of transferring powers to places, increasing the capacity of local self-government and expanding its powers, transferred from the "centre to the grassroots level of territorial communities" on the principles of subsidiary, is an objective basis of decentralization, and at the same time, it is an integral part of the processes of reforming the territorial organization of power (Bila, 2015).

Land resources are an important factor in strengthening the financial self-sufficiency of territorial communities, especially in the context of decentralization of power. The unification of territorial communities creates favourable conditions for the growth of local budget revenues by improving the administration of land fees. Decentralization in the field of land relations will allow territorial communities to determine the land tax rate themselves. Communities should pay special attention to land fees. The land was, is and will be, and it should take appropriate fee. The tax legislation of Ukraine allows local governments to change land tax rates in the range from 0.1 to $3 \%$ of the normative monetary valuation of land, as well as to differentiate tax rates depending on the type of land use.

The normative monetary valuation of settlements' land, methodological provisions of which was developed by domestic scientists and teams of research institutions and design organizations, and gave the opportunity to establish the principles, directions, mechanisms of formation of land taxation, plays an important role in the regulatory policy of the state.

Issues of land taxation are investigated in the writings of such domestic scientists as: D.S. Dobriak, A.G. Martyn, L.Y. Novakovsky, A.M. Tretyak, M.A. Khvesyk and others. However, the present requires the continuation of research in this direction, taking into account the changes that have taken place under the influence of decentralization, which is especially important in the formation of local budgets.

That is why the article analyzes the spatial heterogeneity of land tax rates and the level of tax burden on landowners and land users. 


\section{Methodology of research and materials}

The methodology of studying the problem of land taxation determines that the subject of the study is to determine the influence of local governments on land tax rates. It analyzes the changes in land tax rates in the context of financial decentralization, when local governments of lower levels have the right to independently establish on their territory the rates of many local taxes and fees charged to community budgets. The study of the level of tax burden on landowners and land users, established by local authorities, allowed to reveal the spatial heterogeneity of land tax rates. The tasks were solved using general scientific and special methods, namely: statistical - when generalizing statistical data, analyzing land tax rates; economic analysis - to determine the level of tax burden on landowners and land users; abstract-logical - to substantiate the purpose, objectives and conclusions of the study. The information base of the study was made by the current legislative and regulatory acts, statistical and analytical materials of the State Service of Ukraine for Geodesy, Cartography and Cadastre, Ministry of Finance of Ukraine and State Treasury Service of Ukraine.

\section{Discussion and results}

One of the main economic principles in the land policy of the state is the payment for the use of land. Land fee is an important source of local budgets, since it is fully counted towards the budgets of village, town, city councils and councils of united territorial communities at the location of land. In 2007 , the share of land payments in the structure of tax revenues in local budgets was $8.7 \%$, in 2015 $15.1 \%$, and in $2017-13.1 \%$ (see Figure 1). Land tax and land rent have been and are one of the main components of local tax revenues (Reserves of filling..., 2018).

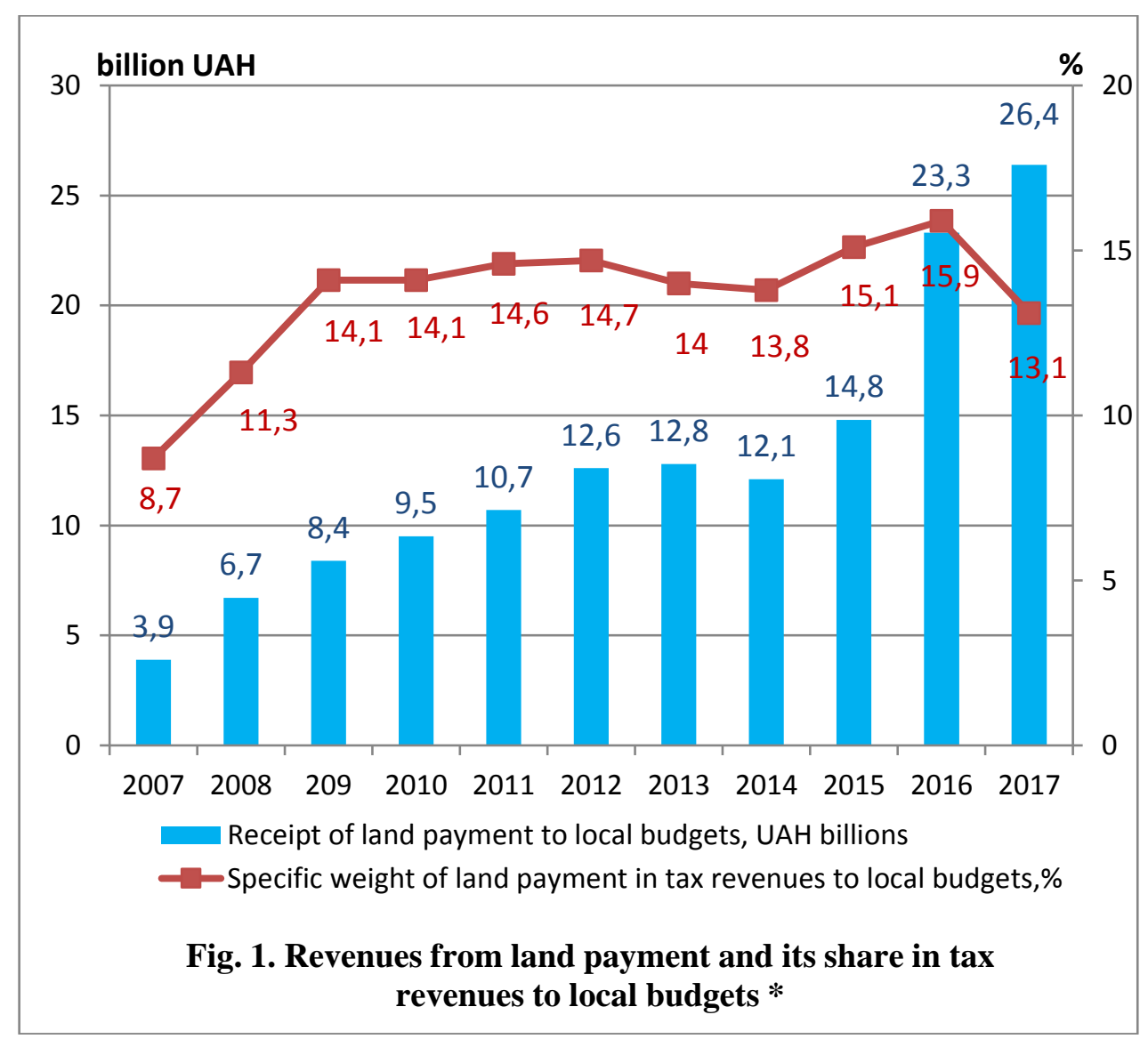

* Calculated according to the data of the Ministry of Finance of Ukraine and the State Treasury Service of Ukraine.

Fig. 1. Land tax and land rent as one of the main components of local tax revenues 
Significant growth in revenues from land payment to local budgets in 2016 and 2017 compared with previous periods is due to the termination of the Law of Ukraine "On Land Fee", which reduced the list of privileges, and the elimination of a fixed agricultural tax, expanded the base of collection land payments. Also, the allocation of payment for land in the category of "local taxes" played a positive role, which in some way influenced the efficiency of the administration of land tax and rent (Golyan, 2018).

Consequently, an important component of effective land relations is a well-balanced fiscal policy in the field of land use. Sustainable development of territorial communities can be ensured by improving the payment of agricultural land use, in particular, from payments for land (Martyn, Lisetskii, 2012).

The completeness of the receipt of funds from the payment for land depends on the powers of the controlling bodies that administer this fee and ensure the completeness and timeliness of payment to the corresponding local budgets of land tax and rent for land plots of state and communal property, as well as the powers of the same local councils, the competence of which is to decide on the establishment of payment for land in the respective territories, the completeness of the registration of all the land parcels actually used, which should ensure Ghana Derzhheokadastru and, of course, the proper exchange of information between all these bodies on subjects and objects of taxation of the land matched the result can ensure the proper collection of the fee.

Every year changes are made to the Tax Code of Ukraine, which change the procedure of taxation of individual taxes and fees. Thus, from January 1, 2019, the Law of Ukraine dated November 23, 2018 No. 2628-VIII "On Amendments to the Tax Code of Ukraine and certain other legislative acts of Ukraine regarding the improvement of the administration and revision of the rates of certain taxes and duties" came into force (Law of Ukraine On Amendments..., 2018). The changes and issues related to land payments, in particular, regarding the powers of local councils and the size of land tax rates, did not go away.

In accordance with clause 8.3 of Art. 8 of the Tax Code of Ukraine to local taxes and fees that are established in accordance with the list and within the limits of the maximum rates determined by this Code, decisions of village, town, city councils and councils of the joint territorial communities, established in accordance with the law and the prospective plan the formation of community territories within their authority and are obligatory for payment in the territory of the respective territorial communities (Tax Code of Ukraine, 2010).

Consequently, land tax, which is a part of the local taxes in the property tax, is implemented on the territory by the decisions of the village, settlement, city councils and councils of the united territorial communities. Therefore, when taxing land plots for land for payers is important is the correct application of relevant decisions of local councils. In turn, local councils in making such decisions should not exceed the powers granted to them, which are specified in Article 12 of the Tax Code of Ukraine. Thus, according to clause 12.3 of Art. 12 of the Tax Code of Ukraine, village, settlement, city councils and councils of united territorial communities established in accordance with the law and the prospective plan for the formation of community territories, within the limits of their authority, make decisions on the establishment of local taxes and fees. Establishment of local taxes and fees shall be carried out in accordance with the procedure established by this Code (Tax Code of Ukraine, 2010).

Having analyzed the level of tax in more than 9.6 thousand territorial communities, it was found that the tax rates for landowners and land users established by the local self-government bodies depend on the economic development of the regions and on the size of the normative monetary valuation of land that is used in Ukraine as a tax base (Figures 2-7). 


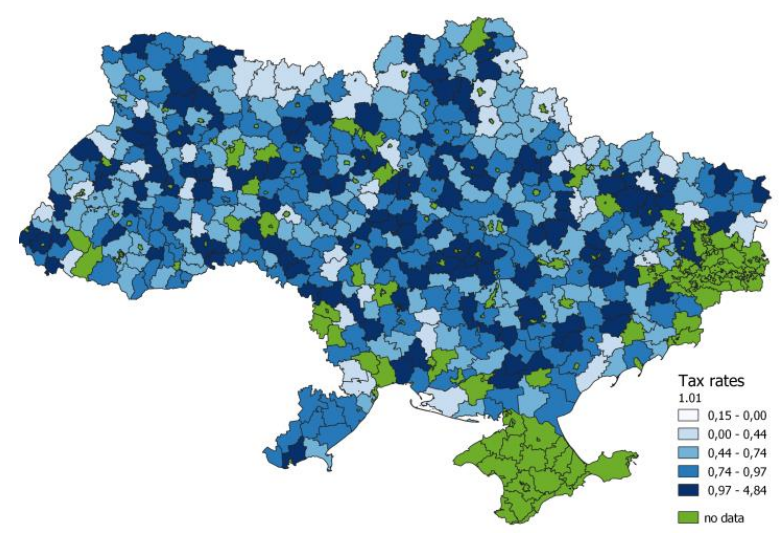

Fig. 2. Tax rates for commercial agricultural production, as of 01.01.2019

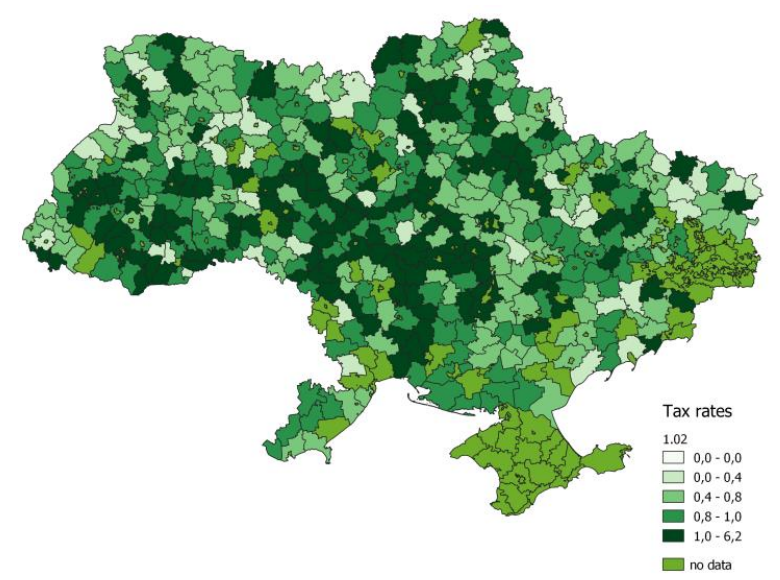

Fig. 4. Tax rates for farming, as of 01.01.2019.

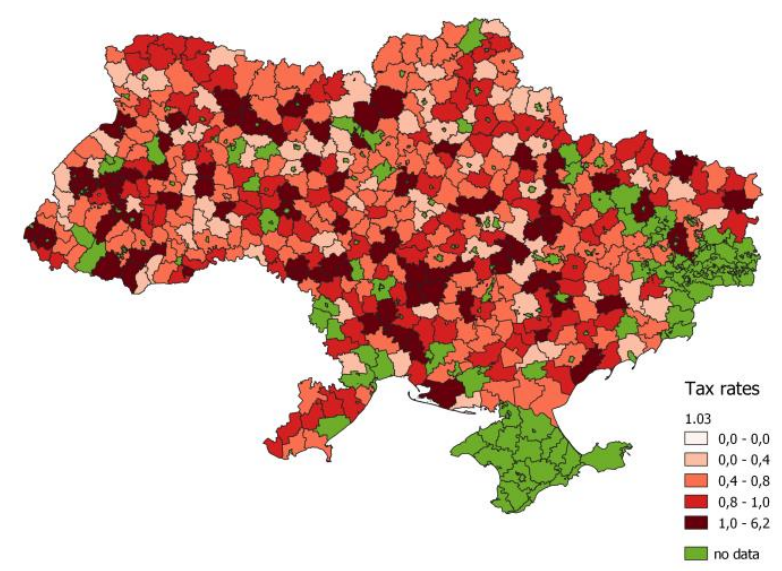

Fig. 6. Tax rates for conducting a private farm, as of 01.01 .2019

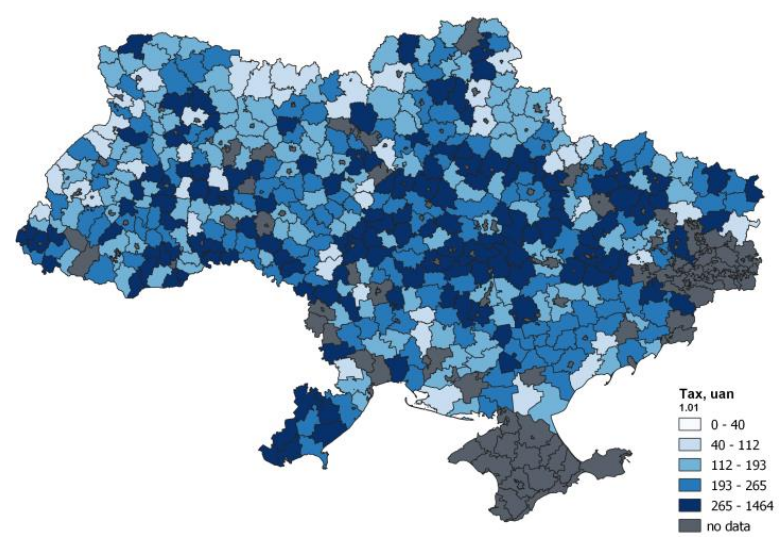

Fig. 3. The size of payment for land for commercial agricultural production on the basis of normative monetary valuation of arable land, as of 01.01 .2019

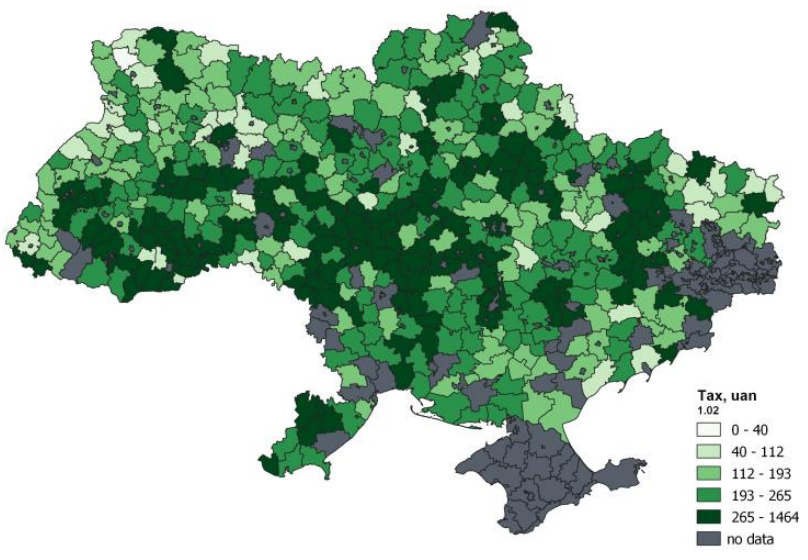

Fig. 5. The size of the payment for the land for farming on the basis of the normative monetary valuation of arable land, as of 01.01.2019

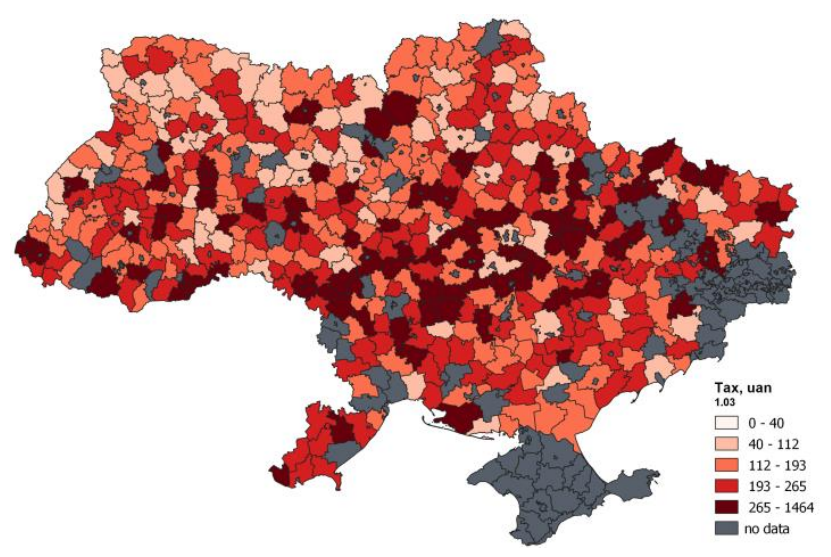

Fig. 7. The size of the payment for conducting a private farm on the basis of normative monetary valuation of arable land, as of 01.01.2019

As we see, there is no clear territorial dependence of land tax rates on normative monetary valuation. In addition, even within the same area, land tax rates can vary by almost 6 times. For example, let's consider the differentiation of the land tax of agricultural land by type of intended use in the Vinnytsia region, the vast majority of whose land is used for agricultural purposes and is a well-known agricultural region (Table 1). 
Table 1.

Differentiation of the land tax for agricultural land in the Vinnytsia region, as of 01.01.2019

\begin{tabular}{|c|c|c|c|c|c|}
\hline \multirow[t]{2}{*}{ № } & \multirow[b]{2}{*}{ The name of the area } & \multirow[b]{2}{*}{$\begin{array}{c}\text { Normative } \\
\text { monetary } \\
\text { valuation } \\
1 \text { ha of arable } \\
\text { land, UAH }\end{array}$} & \multicolumn{3}{|c|}{ Types of purpose land use } \\
\hline & & & $\begin{array}{l}\text { for the conduct of } \\
\text { commodity } \\
\text { agricultural } \\
\text { production }\end{array}$ & for farming & $\begin{array}{l}\text { for conducting } \\
\text { a private farm }\end{array}$ \\
\hline 1 & Barsky & 21727.32 & 1.15 & 1.04 & 0.63 \\
\hline 2 & Bershadsky & 32506.31 & 1.08 & 2.55 & 0.72 \\
\hline 3 & Vinnitsa & 23469.82 & 1.39 & 1.44 & 1.26 \\
\hline 4 & Haysinsky & 27794.18 & 0.45 & 2.30 & 0.34 \\
\hline 5 & Illinetsky & 26035.72 & 1.03 & 1.00 & 1.00 \\
\hline 6 & Koziatynsky & 30484.02 & 1.38 & 1.34 & 0.60 \\
\hline 7 & Kalinovsky & 29250.77 & 0.53 & 0.49 & 0.63 \\
\hline 8 & Kryzhopolsky & 30106.07 & 0.80 & 0.85 & 0.80 \\
\hline 9 & Lipovetsky & 30919.64 & 0.82 & 0.88 & 0.82 \\
\hline 10 & Litinsky & 21122.35 & 1.15 & 1.07 & 1,14 \\
\hline 11 & Mohyliv-Podilsky & 25472.48 & 0.50 & 0.34 & 0.92 \\
\hline 12 & Murovani Kurylivtsi & 21754.31 & 0.76 & 0.88 & 0.90 \\
\hline 13 & Nemirovsky & 23933.67 & 0.94 & 0.96 & 0.86 \\
\hline 14 & Orativsky & 28072.73 & 0.82 & 0.82 & 0.73 \\
\hline 15 & Sandstone & 29159.96 & 1.84 & 1.67 & 1.56 \\
\hline 16 & Pogrebishchensky & 26768.31 & 1.00 & 1.00 & 1.00 \\
\hline 17 & Teplicki & 32890.39 & 0.93 & $0 ., 93$ & 0,84 \\
\hline 18 & Tomashpilsky & 26148.62 & 0.53 & 0.52 & 0.47 \\
\hline 19 & Trostyanetsky & 27032.14 & 0.56 & 2.08 & 0.34 \\
\hline 20 & Tulchinsky & 24546.00 & 0.33 & 0.33 & 0.32 \\
\hline 21 & Tyvrivsky & 21982.56 & 0.90 & 1.59 & 1.02 \\
\hline 22 & Khmelnytsky & 29961.27 & 0.86 & 1.35 & 0.61 \\
\hline 23 & Chernivtsi & 28986.94 & 0.77 & 0.84 & 0.83 \\
\hline 24 & Chethelnitsky & 29513.37 & 0.97 & 0.98 & 0.65 \\
\hline 25 & Shargorodsky & 22645.20 & 0.56 & 0.53 & 0.40 \\
\hline
\end{tabular}

The table shows how the level of tax burden on landowners and land users, established by local authorities, correlates with the economic development of the regions, as well as the normative monetary valuation of land used in Ukraine as a tax base. As you can see, the mechanism of payment for land for today does not work perfectly. So, the highest normative monetary valuation in Teplitskiy (32890.39 UAH / ha) and Bershadsky (32506.31 UAH / ha), and the tax rates in these areas differ considerably: in Teplitsky for commercial agricultural production for - 0.93 , for the management of the farm -0.93 , for the personal farm management -0.84 , and in Bershadsky respectively -1.08 , $2.55,0.72$. Since land payments are an important source of budget revenues, the land-use payment system needs to be improved.

However, one can not unequivocally attribute the payment of land to property taxes. In addition to the payment for land, the property tax includes a tax on immovable property, different from the land plot. The tax rates for residential and / or non-residential real estate owned by individuals and legal entities are established by the decision of a village, settlement, city council or council of united territorial communities established in accordance with the law and a prospective plan for the formation of community territories, depending on the location (zoning) and types of such real estate at a rate not exceeding 1.5 per cent of the minimum wage, established by law on January 1 of the reporting (tax) year, per 1 square This is the tax base meter.

Today we used methods of calculating tax liabilities are imperfect and do not provide nor justice nor protection from corrupt abuse as requiring improvement. Land should be subject to taxation, taking into account the way of use, and not measured inside real estate objects. The tax rate should be the same for all countries, in particular. Neither individual civil servants or public authorities and local governments will have no impact on the amount of tax liabilities of taxpayers.

The approach in Ukraine to the taxation of real estate, different from the land plot, does not take into account the valuation of property, but defines the tax base, based simply on the area. This, of course, 
simplifies administration. However, this method is unfair, because it does not take into account the differences in location and does not allow to reveal the positive potential of the property tax.

Excluding the tax on real property other than land, with land tax system will get the same rate of land tax throughout.

\section{Conclusions and proposals}

The fee for land has been and is one of the main components of tax revenues to local budgets. Land tax in a well-developed economy, especially at the local level, is a constant source of public expenditure on education, health care, infrastructure support for settlements, and the reproduction of land resources. Consequently, he must not only cope annually but also be an effective tool for the development of the territory.

As a result of our research, we found that local governments in Ukraine set the land tax in the range from 0.03 to $6.15 \%$, which in absolute terms ranges from 6.54. Up to 1961.11 UAH per hectare. The highest tax rates are concentrated in the Kyiv and Vinnytsia regions, due to the fact that there are the highest rates of agriculture. At the same time, it should be noted that in Ukraine as a base for taxation of land, a normative monetary valuation of land is used, which is not based on the market value of land. This requires further improvement of taxation mechanisms, and tax rates in the present conditions can be used as an instrument that allows modelling the actual amount of tax payments in a situation where the tax base does not give an objective picture of the value of taxed areas.

\section{References}

1. Bila S. (2015). The Impact of Decentralization on Stimulating the Economic Growth of Territorial Communities in Ukraine. Scientific Journal of NP Drahomanov NPU, Volum 27, pp. 60-68.

2. Golyan V. (2018). Land decentralization as an institutional barrier to land redistribution. ZN.UA, Volume 11, (https://dt.ua/macrolevel/zemelna-decentralizaciya-yak-institucionalniy-bar-yer-zemelnomu-peredilu273037 .html).

3. Martyn A., Lisetskii V. Платність сільськогосподарського землекористування в Україні потребує реформування (2012 [). Payments for agricultural land use in Ukraine require reformation. Land Management and Cadastre], Volum 1, pp. 50-55 (in Ukrainian).

4. Закон України Про внесення змін до Податкового кодексу України та деяких інших законодавчих актів України щодо покрашення адміністрування та перегляду ставок окремих податків і зборів Law of Ukraine (On Amendments to the Tax Code of Ukraine and some other legislative acts of Ukraine on improving the administration and revision of the rates of certain taxes and duties) (2018). Vidomosti Verkhovnoyi Rady No 49, 399 pp.(in Ukrainian)

5. Податковий кодекс України (Tax Code of Ukraine) (2010). Ofitsiynyy visnyk Ukrayiny No 92, 3248 pp.(in Ukrainian)

6. Khotenko O., Smirnova O. (2017). Tax sources of local budget revenues.[Податкові джерела доходів місцевих бюджетів], Tax Reform Institute NGO website, (http://ngoipr.org.ua/blog/podatkovidzhereladohodiv-mistsevyh-byudzhetiv/) (in Ukrainian)

7. Vdovichenko A., Kozoriz L., Paskalova A., Pirnikoza P., Serebryansky D., Sibiryanska Y., Stadnik M. [for title ed. Mazarchuk V.] Податки і збори: сучасні тенденції та перспективи (2019). (Taxes and fees: current trends and prospects). FOP Lopatin O.O. Kiev, 392p. (in Ukrainian)

8. Резерви наповнення місцевих бюджетів за рахунок продажу земель у межах населених пунктів практично вичерпані - експерт (Reserves of filling local budgets due to land sales within settlements are almost exhausted - expert) (2018) (https://dt.ua/ECONOMICS/rezervi-napovnennya-miscevih-byudzhetiv-zarahunok-prodazhu-zemel-u-mezhah-naselenih-punktiv-praktichno-vicherpani-ekspert-273109 _html) Ukrainian)

Information about authors:

Liudmyla Hunko, Ph.D, Assoc. Prof., Land-Use Planning Department, National University of Life and Environmental Sciences of Ukraine. Address: 17 Valylkivska str., Kyiv, 03040, Ukraine; phone: +380503821744; e-mail: liudmyla_g@ukr.net. Fields of interest: land management, land administration, spatial planning, property taxes.

Yuliia Moroz, Master of Science, Ph.D.-student, Department of the Land-Use Planning, University of Life and Environmental Sciences of Ukraine. Address: 17 Valylkivska str., Kyiv, 03040, Ukraine; phone: +380637894752; e-mail: yulia_moroz1994@ukr.net ; Fields of interest: land management, land administration, spatial planning, property taxes. 